\title{
AKTUALISASI SIKAP KEAGAMAAN DALAM RANAH SOSIAL (Rekonstruksi Peran IPS dalam Pengembangan Sikap Keagamaan)
}

\author{
Mohammad Imam Farisi*
}

${ }^{1}$ Program Studi/Jurusan Pendidikan IPS/PKn FKIP Universitas Terbuka UPBJJ - UT Surabaya

\begin{abstract}
Abstrak: Dalam sejarah pendidikan di Indonesia, setidaknya telah terjadi delapan kali perubahan kurikulum, diantaranya adalah kurikulum 2013 (K-13) yang sekaligus merupakan kurikulum pertama yang memiliki dasar-dasar pemikiran yang progresif. Ini terkait dengan penggunaan filsafat Rekonstruksionisme Sosial dan teori Gestalt sebagai landasan pengembangannya. Atas dasar kedua teori-filsafat itu pula, Kurikulum 2013 mampu mewahanai prinsip keterpaduan, keutuhan, atau integralitas antar-konten atau isi kurikulum; antara konten kurikulum dengan realitas kehidupan; dan berorientasi pada pembentukan pengetahuan, sikap, dan keterampilan fungsional secara terintegrasi. Termasuk integrasi kajian keagamaan di dalam semua mata pelajaran di sekolah. Tulisan ini mengkaji dan mendeskripsikan dimensi-dimensi sikap keagamaan dalam kurikulum 2013, baik dalam mata pelajaran Pendidikan Agama, maupun mata-mata pelajaran lain; integrasi kompetensi sikap keagamaan dalam IPS; dan model pengorganisasian pembelajaran IPS-Tematik dalam rangka pembentukan dan aktualisasi sikap keagamaan dalam realitas kehidupan bermasyarakat, berbangsa, dan bernegara.
\end{abstract}

Kata kunci: abstrak, esensi penelitian, mesin pencari.

Dalam sejarah pendidikan di Indonesia, setidaknya telah terjadi delapan kali perubahan kurikulum, diantaranya adalah kurikulum 2013 (K-13) yang sekaligus merupakan kurikulum pertama yang memiliki dasar-dasar pemikiran yang progresif. Ini terkait dengan penggunaan filsafat Rekonstruksionisme Sosial dan teori Gestalt sebagai landasan pengembangannya. Atas dasar kedua teori-filsafat itu pula, Kurikulum 2013 mampu mewahanai prinsip keterpaduan, keutuhan, atau integralitas antar-konten atau isi kurikulum; antara konten kurikulum dengan realitas kehidupan; dan berorientasi pada pembentukan pengetahuan, sikap, dan keterampilan fungsional secara terintegrasi. Termasuk integrasi kajian keagamaan di dalam semua mata pelajaran di sekolah. Tulisan ini mengkaji dan mendeskripsikan dimensi-dimensi sikap keagamaan dalam kurikulum 2013, baik dalam mata pelajaran Pendidikan Agama, maupun mata-mata pelajaran lain; integrasi kompetensi sikap keagamaan dalam IPS; dan model pengorganisasian pembelajaran IPS-Tematik dalam rangka pembentukan dan aktualisasi sikap keagamaan dalam realitas kehidupan bermasyarakat, berbangsa, dan bernegara.

Kata kunci: abstrak, esensi penelitian, mesin pencari

*Alamat korespondensi: Kampus C Unair, Surabaya 60115

e-mail: imamfarisi@ecampus.ut.ac.id 


\section{PENDAHULUAN}

Pendidikan ideal hakikatnya bersifat "antisipatoris" dan "prepatoris", mengacu ke masa depan, dan mempersiapkan generasi muda untuk kehidupan masa depan yang lebih baik, bermutu, dan bermakna (Buchori, 2001). Pendidikan ideal bagi bangsa Indonesia adalah pendidikan yang mampu mengembangkan segala kapasitas peserta didik sebagai warga negara demokratis serta bertanggung jawab, yaitu warga negara yang memiliki kekuatan spiritual keagamaan, pengendalian diri, kepribadian, kecerdasan, akhlak mulia, serta keterampilan, melalui proses "pembuda-yaan dan pemberdayaan" (UU Nomor 20 tahun 2003). Namun demikian, se-jumlah pakar pendidikan memandang bahwa selama ini sistem pendidikan nasional (sisdiknas) masih belum menjadi pranata pembudayaan dan pemberdayaan.

Fenomena ini terjadi sejak tahun 1960an, ketika sisdiknas mulai kehilangan momentum untuk mengikhtiarkan pembentukan dan pengembangan kesadaran akan harkat dan martabat bangsa; serta kehilangan watak kultural yang patut dibanggakan, karena pendidikan telah menjadi kepanjangan tangan birokrasi dalam upaya menanamkan kepentingannya (Buchori, 2001). Sisdik-nas telah gagal menghasilkan kader-kader bangsa yang berkemauan tulus dan berkemampuan profesional. Akibatnya, kehidupan berbangsa dan bernegara Indonesia dewasa ini semakin hilang dan menjauh dari jatidiri bangsa (Supriyoko 2001). Hal ini juga dapat diamati dari kecenderungan terjadinya kenakalan remaja, kemerosotan moral, dan perilaku menyimpang dari etika kehidupan dan budaya bangsa. Sekolah yang diharapkan menjadi agen pembaharuan belum sepenuhnya menjadi wahana proses transformasi nilai-nilai dan norma-norma kebangsaan (Koster, 2000).

Faktor utama belum berfungsinya pendidikan sebagai pranata pembudayaan dan pemberdayaan adalah, bahwa sisdiknas masih sangat berorientasi pada pengembangan intelektual. Sedangkan pengelolaan pendidikan yang cenderung berorientasi pada pengembangan intelektual dan mengabaikan dimensi-dimensi lain manusia, justru hanya akan melahirkan manusia Indonesia dengan kepribadian pecah (split personality) (Fajar, et.al., 2001).

Pendidikan agama yang sangat diharapkan berperan sentral dalam pendidikan karakter, juga dipandang masih lemah, karena hanya menyentuh aspek kognitif, pengenalan norma atau nilainilai, belum pada tingkatan interna-lisasi (afektif), dan tindakan nyata dalam kehidupan sehari-hari yang sesungguhnya inti pembelajaran agama. Akibatnya, kesenjangan antara pengetahuan dan perilaku 
keagamaan semakin melebar (Kosim, 2011).

Pendidikan kita seringkali hanya sebatas transfer ilmu dan tidak membangun karakter anak didik. Siswa tidak diberi kesempatan untuk merefleksikan dan memposisikan dirinya dalam sistem pendidikan yang semata-mata untuk kepentingan dunia kerja. Kegiatan refleksi yang di dalam pendidikan itu sangat penting, kini telah kehilangan tempat. Kurikulum berdasarkan kompetensi pun tidak mengarah ke pembentukan karakter, dan masih berbasis disiplin ilmu (Hasan, 2002).

Dari sekian banyak unsur sumber daya pendidikan, kurikulum merupakan salah satu unsur yang bisa memberikan kontribusi yang signifikan untuk mewujudkan proses berkembangnya kualitas potensi peserta didik. Kurikulum sebagai unsur strategis dalam pendidikan sekolah yang memiliki makna penting dalam mengemban peran sekolah sebagai pusat pembudayaan dan pemberdayaan (Soedijarto, 2004).

Secara pedagogis, kurikulum adalah rancangan pendidikan yang mem-beri kesempatan untuk peserta didik mengembangkan potensi dirinya dalam suatu suasana belajar yang menyenangkan dan sesuai dengan kemampuan dirinya untuk memiliki kualitas yang diinginkan masyarakat dan bangsanya. Secara yuridis, kurikulum adalah suatu kebijakan publik yang didasarkan kepada dasar filosofis bangsa dan keputusan yuridis di bidang pendidikan (Kemendikbud, 2012).

Namun, realitasnya kurikulum kini tak ubahnya seperti mesin, sedangkan remote control-nya sepenuhnya berada di birokrasi. Institusi sekolah sama sekali tak memiliki ruang dan daya untuk mengembangkan diri, hanya mengabdi semata-mata pada keputusan dari atas yang lebih sering tak tepat pemikiran dasar maupun praktik pelaksanaannya (Buchori, 2001).

Refleksi Suyanto (2003) terhadap perubahan kurikulum, juga menyimpulkan bahwa kurikulum pendidikan di Indonesia belum mampu melahirkan unjuk kerja siswa secara bermakna. Siswa banyak tahu informasi, tetapi tidak bermakna bagi kehidupannya. Me-nurutnya, pendidikan di Indonesia mengutip pendapat Freire cenderung mengikuti "banking concept of education". Guru hanya mendepositokan banyak informasi yang diturunkan dari berbagai cabang ilmu kepada siswa, tetapi tidak pernah membicarakan untuk apa informasi itu harus dikuasai siswa. Lombok (2003) juga menyimpulkan bahwa kelemahan pokok kurikulum hingga kini adalah tingkat relevansi rendah, kurang memberi pengalaman belajar kepada siswa untuk 
membentuk kompetensi, dan lebih "content oriented".

Dalam sejarah pengembangan kurikulum sekolah di Indonesia, setidaknya telah terjadi delapan kali perubahan. Diantara kedelapan kurikulum tersebut, kurikulum 2013 dapat dipandang sebagai ikhtiar dan produk akademik yang didasarkan atas hasil penilaian nasional pendidikan (national assessment), setelah kurikulum 1975 dan kurikulum PPSP (Proyek Perintis Sekolah Pembangunan (1974-1981) (Soedijarto, 2004).

Secara struktural-substantif, Kurikulum 2013 juga memiliki harapan lebih besar untuk mewujudkan pendidikan sebagai pranata pembudayaan dan pemberdayaan, khususnya bagi pengembangan sikap keagamaan secara terintegrasi. Hal ini terkait dengan penggunaan filsafat Rekonstruksionisme Sosial dan teori Gestalt sebagai landasan pengembangannya.

Rekonstruksionisme sosial menjadi landasan filosofis-teoretis dalam rekonstruksi organisasi konten/isi, bahan belajar, dan mata pelajaran; dan teori Gestalt menjadi landasan teoretis dalam rekonstruksi organisasi pembelajaran. Penggunaan filsafat rekonstruksionisme sosial dan teori Gestalt yang menekankan pada keterpaduan, keutuhan, atau integralitas antar-konten atau isi kurikulum, dan antara konten kurikulum dengan realitas kehidupan; serta orien- tasinya pada pembentukan pengetahuan, sikap, dan keterampilan fungsional, dipandang sebagai responsolutif kurikulum 2013 atas kebutuhan masyarakat dan bangsa dalam membangun generasi muda bangsanya.

Tulisan ini mengkaji dan mendeskripsikan dimensi-dimensi sikap keagamaan dalam kurikulum 2013, integrasi kompetensi sikap keagamaan dalam IPS; dan IPS-Tematik sebagai model pengorganisasian pembelajaran dalam rangka pembentukan dan aktualisasi sikap keagamaan dalam realitas kehidupan bermasyarakat, berbangsa, dan bernegara.

\section{METODE PENELITIAN}

Penelitian ini menggunakan metode "analisis konten kualitatif" (qualitative content analysis). Sebuah teknik analisis yang lebih menekankan pada aktivitas "the subjective interpretation" peneliti terhadap konten/isi teks sebagai data, melalui proses kodifikasi dan indentifikasi tematema atau pola-pola spesifik dan menonjol (emergent), dan mengungkap "makna" (meanings) yang terdapat di dalam objek kajian (Zhang \& Wildemuth, 2009; Stemler, 2012).

Objek kajian atau interpretasi adalah "teks-teks" atau "narasi tekstual" (kata, frase, kalimat, paragraf, atau dokumen tekstual secara keseluruhan) yang terdapat di dalam dokumen Kurikulum 2013 untuk jenjang SD/MI hingga SMA/MA. Sebagai 
objek kajian, teks Kurikulum 2013 menurut Ricoeur (1991) "is any discourse fixed by writing...fixation by writing is constitutive of the text itself" (h. 106).

Untuk mendokumentasikan seluruh data digunakan alat bantu pengumpul data berupa "written reflective exercises", "reflective notes" atau "interpretive memos" (Zhang \& Wildemuth, 2009). Catatan berisi: (1) identitas dokumen/ sumber data; (2) pertanyaan/tema pengkategori data; (3) kutipan-kutipan kata, frase, kalimat, atau paragraf dari dokumen Kurikulum 2013 yang dipandang sebagai “exemplars' yang merepre-sentasikan fokus penelitian; (4) dan catatan/ringkasan interpretasi-refleksi kritis peneliti atas data dan reviu teori/studi terdahulu yang relevan dengan data.

Kedua instrumen tersebut digunakan untuk membantu peneliti melakukan interpretasi reflektif terhadap pola-pola, kecenderungan, isu-isu, atau fenomena-fenomena yang dianggap spesifik, bermakna, penting atau menonjol terkait dengan konstruksi kewarganegaraan dalam konteks community civics sebagaimana dinarasikan secara tekstual di dalam dokumen Kurikulum 2013 yang dikaji.

HASIL DAN PEMBAHASAN
1. Sikap Keagamaan
Kurikulum 2013

Di dalam kurikulum 2013, sikap keagamaan merupakan salah satu dari empat Kompetensi Inti (KI), yaitu 'sikap keagamaan' (KI-1). KI-sikap keagamaan ini merupakan kompetensi yang berlaku untuk semua mata pelajaran, dan harus dikuasai oleh setiap peserta didik dari jenjang SD/MI hingga SMA/MA. Rumusan KI-sikap keagamaan untuk jenjang SD/MI hingga SMA/MA seba-gai berikut: (1) menerima dan menjalankan ajaran agama yang dianutnya (kelas IIII SD/MI); (2) menerima, menjalankan, dan menghar-gai ajaran agama yang dianutnya (kelas V-VI SD/MI); (3) menghargai dan menghayati ajaran agama yang dianutnya (kelas VII-IX SMP/MTs); dan (4) menghayati dan mengamalkan ajaran agama yang dianutnya (kelas X-XII SMA/MA).

Keempat KI-sikap keagamaan tersebut dijabarkan lebih lanjut ke dalam KD-KD mata pelajaran Pendidikan Agama, dan mata-mata pelajaran pada jenjang SD/MI hingga SMA/MA, baik pada mata pelajaran wajib seperti PPkn, Bahasa Indonesia, Bahasa Inggris, IPA, IPS, Seni, Budaya, dan Prakarya, dan Pendidikan Jasmani, Olahraga dan Kesehatan, maupun mata pelajaran peminatan SMA/MA (Matematika dan Ilmu-Ilmu Alam, Ilmu-Ilmu Sosial, dan Ilmu-ilmu Bahasa dan Budaya). Pada mata pelajaran Pendidikan Agama, 
pengembangan KI-sikap keagamaan selain dijabarkan secara langsung di dalam KD-KD untuk KI-1, juga dikembangkan secara tidak langsung (indirect teaching) melalui KD-KD untuk KI-2 (sikap sosial); KI-3 (pengetahuan) dan KI-4 (penerapan pengetahuan) (Kemendikbud, 2013a; 2013b; 2013c). Sedangkan pada mata-mata pelajaran selain Pendidikan Agama, KD-KD sikap keagamaan dikembangkan pada kontenkonten tertentu yang memiliki keterkaitan dan dapat mengkontribusi pengembangan sikap keagamaan peserta didik pada dimensi kognitif, afektif, dan konatif.

Pengembangan KI-sikap keagamaan di dalam mata pelajaran selain Pendidikan Agama dilakukan sejalan dengan prinsip 'eklektik' dan 'terintegrasi' dalam organisasi konten/kompetensi kurikulum. Dengan struktur organisasi konten/kompetensi seperti itu, pengembangan KI sikap keagamaan ke dalam KD-KD dapat tercipta secara terintegrasi (vertikal dan horizontal) pada seluruh mata pelajaran, jenjang kelas, dan sekolah, dengan bobot kompetensi yang semakin tinggi. Prinsip eklektivisme dan integrasi konten dipandang mampu menjamin keterpa-duan, keutuhan, atau integralitas antar-konten atau isi kurikulum, dan antara konten kurikulum dengan realitas kehidupan. Selain itu, orientasi kurikulum 2013 pada pembentukan pengetahuan, sikap, dan keterampilan fungsional, juga dapat dipandang sebagai respon-solutif kurikulum atas kebutuhan masyarakat dan bangsa dalam membangun generasi muda bangsanya.

Selain itu, jumlah beban belajar Pendidikan Agama di dalam kurikulum 2013 untuk setiap jenjang sekolah (SD/MI s.d. SMA/MA) adalah 3-4 jam per minggu. Ini berarti bahwa jumlah jam belajar untuk Pendidikan Agama hanya 120 menit per minggu untuk jenjang SD/MI dan SMP/MTs; dan 180 menit per minggu untuk jenjang SMA/MA; atau rerata sekitar $10 \%$ dari total jumlah jam pelajaran di sekolah. Dengan jumlah jam seperti itu, tentu sangat tidak memungkinkan bagi mata pelajaran Pendidikan Agama untuk membentuk pengetahuan, sikap, dan perilaku keagamaan peserta didik secara purna. Kontribusi secara sinergis dari mata-mata pelajaran lain bagi pemben-tukan kompetensi sikap keagamaan mutlak diperlukan, sesuai dengan substansi dan karakteristik masing-masing mata pelajaran. Namun demi-kian, hasil analisis dokumen kurikulum 2013 menunjukkan bahwa penjabaran KI sikap keagamaan ke dalam KD-KD tak tampak pada mata pelajaran Mate-matika kelas I-VI SD/MI; kelas VII dan VIII SMP/MTs; kelas X-XII SMA/MA (kelompok wajib dan peminatan). Selain itu, pengembangan KI-sikap keagamaan juga tak dikem- 
bangkan di dalam KD-KD mata pelajaran kelompok peminatan, seperti Bahasa dan Sastra Arab, Jepang, Mandarin, Jerman, dan Perancis.

\section{Integrasi Kompetensi Sikap} Keagamaan dalam IPS

Secara filosofis, IPS adalah "integrative science" dan "integrative social studies", yaitu mata pelajaran yang mempelajari totalitas pengalaman manusia dalam kontinum ruang dan waktu dengan mengintegrasikan beragam konten dan unsur disiplin ilmu-ilmu sosial, arkeologi, psikologi, seni, sains, humaniora, dan realitas kehidupan manusia. Gagasan IPS integratif pertama kali dikemukakan di dalam dokumen National Council for the Social Studies (NCSS) tahun 1989 (NCSS, 1989). Di dalam dokumen tersebut dinyatakan, bahwa salah satu karakteristik kurikulum IPS abad ke-21 adalah pengintegrasian seluruh kajian ilmu-ilmu sosial dari jenjang TK hingga jenjang kelas 12 (K12), untuk menyediakan sebuah matriks atau framework bagi IPS yang memungkinkan peserta didik memiliki pengertian utuh atas prinsip-prinsip dan metodologi dalam ilmu-ilmu sosial.

Sifat integratif ini diformulasikan lebih lanjut tahun 1992 oleh Gugus Tugas NCSS untuk mengembangkan standarstandar IPS, dalam rangka memantapkan konsep integrasi antara ilmu-ilmu sosial, ilmu perilaku, dan humaniora bagi pencapaian kompetensi akademik dan kewarganegaraan (NCSS, 1994). Akhirnya, tahun 1994 IPS inte-gratif dimantapkan sebagai salah satu dari visi IPS sebagai program pendidikan di sekolah. "Social studies teaching and learning are powerful when they are integrative". Dengan visi tersebut, tujuan IPS adalah menyiapkan peserta didik menjadi warga negara yang demo-kratis, mampu berpikir spekulatif, kritis, membuat keputusan personal dan kewarganegaraan berdasarkan informasi dari berbagai perspektif. Pembelajaran IPS juga diharapkan memberikan pengalaman belajar komprehensif kepada peserta didik tentang berbagai dilema kehidupan yang multi-perspektif, multikonfrontatif, dengan menyediakan bera-gam strategi dan aktivitas yang meli-batkan peserta didik dengan ide-ide bermakna, mendorong mereka membangun kaitan antara pengetahuan-awal dengan isu-isu mutakhir, berpikir kritis dan krea-tif atas apa yang mereka pelajari, dan mengaplikasikannya di dalam situasi otentik.

Sejumlah studi menunjukkan bahwa IPS-terpadu mampu meningkatkan kemampuan berpikir kritis; dan memungkinkan peserta didik baik individual maupun kelompok aktifpartisipatif mencari, menggali, dan menemukan konsep serta prinsip secara 
holistik. Melalui pembelajaran terpadu peserta didik juga dapat memperoleh pengalaman langsung, sehingga dapat menambah kekuatan untuk menerima, menyimpan, dan memproduksi kesankesan tentang hal-hal yang dipelajarinya. Mereka juga terlatih untuk dapat menemukan sendiri berbagai konsep yang dipelajari. Namun demikian, Noviani (2010) mengingatkan bahwa pembelajaran terpadu membutuhkan waktu, kejelian, ketepatan memetakan kompetensi dasar menjadi tema tertentu juga membutuhkan pengamatan aspek afektif siswa serta kesiapan semua pihak, yaitu guru dan siswa.

Sejalan dengan visi NCSS tersebut, mata pelajaran IPS di dalam kurikulum 2013 dinyatakan "bukan pendidikan disiplin ilmu", melainkan pendidikan yang berorientasi aplikatif, pengembangan kemampuan berpikir, kemampuan belajar, rasa ingin tahu, dan pengembangan sikap peduli dan bertanggung jawab terhadap lingkungan sosial dan alam (Kemendikbud, 2013b). Hakikat IPS ini merupakan hal baru, yang sama sekali berbeda dibandingkan pemaknaan sebelumnya, bahwa IPSsecara akademik dan kurikulum adalah penyederhanaan, adaptasi, seleksi, dan modifikasi dari konsep-konsep dan keterampilan-keterampilan disiplin ilmu ilmu sosial yang diorganisasikan secara ilmiah dan psikologis untuk tujuan pembelajaran (Somantri, 2000; Depdiknas, 1999; 2002).

Pemaknaan IPS seperti ini telah melahirkan pandangan bahwa IPS adalah 'turunan dari ilmu-ilmu sosial' (Welton \& Malan, 2004) atau 'atau 'bagian dari ilmu-ilmu sosial (Wahab, 1986:5), yang secara filosofis sangat bertolak belakang dari pemikiran kurikulum 2013 yang menegaskan bahwa semua disiplin ilmu adalah sama dalam kedudukannya, dan prinsip eklek-tisisme yang menjadi prinsip dasar pengembangannya. Karena itu, mata pelajaran IPS - juga mata pelajaran lain — dimaknai sebagai sumber konten untuk menguasai kompetensi yang bersifat terbuka, dan tidak selalu diorganisasikan, dan tidak perlu terikat pada kaedah filosofi esensialisme dan perenialisme. Penolakan terhadap model kurikulum esensialis dan perennialis ini, karena keduanya hanya memposisikan peserta didik sebagai 'penerima pasif' (passive recipient) terhadap realitas dan kebenaran yang secara ontologis berada di luar dirinya (Winataputra, 2001a).

Selain itu, model kurikulum esensialis dan perennialis juga dipandang dapat menghambat perkembangan tahapan progresif mereka; mendistorsi dan merusak "genuine concepts" atau "indigenous science" mereka tentang alam semesta yang mereka bangun dan kembangkan dari keseharian pengalaman sosial dan kulturalnya di masya- 
rakat; yang akhirnya akan mendistorsi atau merusak self-concept siswa yang merupakan faktor esensial bagi pembentukan identitas atau karakter mereka (Sumantri, 2002). Studi PISA (Program for International Student Assessment) juga merekomendasikan perlunya perubahan orientasi kurikulum yang tidak membebani peserta didik dengan konten keilmuan secara terpisahpisah, melainkan lebih pada upaya mengembangkan aspek kemampuan esensial, berupa pengetahuan dan keterampilan fungsional secara terintegrasi yang diperlukan oleh semua warga negara untuk berperan serta dalam membangun negara pada masa mendatang. PISA menegaskan bahwa "education systems play a key role in generating the new supply of skills to meet this demand-cross-disciplinary domains or curricular areas (Bussière, Cartwright \& Knighton, 2004:10); dan penekanan pada domain-domain tersebut - matematika, membaca, dan literasi sains_- "should be placed on functional knowledge and skills that allow active participation in society" (Bussière, Knighton \& Pennock, 2007:9).

Dalam konteks kurikulum IPS integratif inilah, pengembangan sikap keagamaan dimungkinkan. Integrasi kajian dan kompetensi sikap keagamaan dalam IPS pertama kali dikembangkan oleh NCSS di dalam kurikulum 1984. Dalam pandangan NCSS, kajian agama dalam IPS merupakan hal yang sangat mendasar. Menghilangkannya hanya akan memberikan kesan kepada siswa bahwa agama bukan bagian dari pengalaman manusia. Sementara, agama terbukti telah mempengaruhi perilaku individu dan negara, dan telah menginspirasi beberapa seni, arsitektur, sastra, dan musik yang paling indah di dunia. Sejarah, pluralisme agama suatu bangsa, dan peristiwa kontemporer di dunia adalah sebuah testimoni, kesaksian, bahwa agama telah dan terus memberikan pengaruh budaya yang penting bagi kehidupan berbangsa dan bernegara. Pengertian tentang keberagaman agama dan perannya dalam dunia kontemporer merupakan bagian esensial dari kurikulum IPS, yang dikaji dalam berbagai dimensi sejarah dan kebudayaan umat manusia secara berimbang dan menyeluruh. Pendidikan agama juga tidak hanya karakteristik bagi pribadi terdidik, melainkan keniscayaan kemanusiaan untuk mengerti dan hidup di dunia yang serba-ragam, dan meningkatkan pengertian dan menghilangkan prasangka (NCSS, 2013).

Kajian keagamaan juga dapat memberikan ruang bagi peserta didik untuk memperoleh pengalaman belajar keagamaan dengan segala hakikat ke- 
percayaan, praktik, institusi keaga-maan yang pervasif dan sensitif (Collie \& Smith, 1981). Inklusi pendidikan agama dalam PIPS juga diyakini sangat berpengaruh pada proses sosialisasi individu dan pembentukan rasa memiliki secara personal peserta didik (Koçoğlu, 2016).

Di dalam standar-standar kurikulum NCSS tahun 1994 dan 1990, sikap keagamaan resmi menjadi salah satu bahan kajian kurikuler, dan terintegrasi di antara 10 tema yang dikembangkan. Bahkan studi Kaymakcan dan Meydan (2012) menyimpulkan, "social studies were found to be ahead of religious education program in terms of reflecting these changing tendencies [from local values towards universal values with the changes made in recent years] in the content of the program" (p. 1588). Namun demikian, Daniel (2011) mengingatkan bahwa substansi pendidikan keagamaan dalam PIPS "needs to be viewed not as a body of knowledge and skills to be unpacked from the world of work, but as a way of guiding and leading towards critical judgment and intelligent choices based on clear concepts, values and beliefs" (p. 52).

Di Indonesia, integrasi kajian keagamaan dan pengembangan sikap keagamaan di dalam IPS untuk pertama kali dilakukan di dalam kurikulum 2013. Pengembangannya sendiri sudah dimulai sejak kelas I SD/MI hingga SMA/MA, terdistribusi dan terintegrasi dalam bahan-bahan kajian sejarah, sosial, ekonomi, geografi, dan budaya. Pada jenjang SD/MI dan SMP/MTs, pengembangannya difokuskan pada pembentukan kesadaran dan sikap peserta didik untuk: (1) memahami manusia, perubahan dan keberlanjutan dalam waktu pada masa Islam dalam aspek pemerintah, sosial, ekonomi, dan pendidikan; (2) menerima karunia Tuhan YME yang telah menciptakan waktu dengan segala perubahannya, manusia dan lingkungannya; dan memberikan kesempatan kepada bangsa Indonesia untuk melakukan perubahan dalam aspek geografis, ekonomi, budaya dan politik; (3) menunjukkan perilaku jujur, disiplin bertanggung jawab, peduli, santun dan percaya diri sebagaimana ditunjukkan oleh tokoh-tokoh pada masa Islam dalam kehidupannya sekarang; dan (4) menjalankan ajaran agama dalam berfikir dan berperilaku sebagai penduduk Indonesia dengan mempertimbangkan kelembagaan sosial, budaya, ekonomi dan politik dalam masyarakat (Kemendikbud, 2013b; Kemendikbud, 2013c).

Pada jenjang SMA/MA, pengembangan kompetensi sikap keagamaan terdistribusi dan terintegrasi pada sejumlah mata pelajaran untuk peminatan ilmuilmu sosial (Sejarah Indonesia, Sosiologi, Ekonomi, Antropologi, Geografi). 
IPS-Sejarah Indonesia memfokuskan pada pembentukan kesadaran dan sikap untuk menghayati dan mensyukuri (1) keteladanan para pemimpin dalam mengamalkan ajaran toleransi antar umat beragama dalam kehidupan sehari-hari; (2) nilai-nilai persatuan dan keinginan bersatu dalam perjuangan pergerakan nasional menuju kemerdekaan bangsa sebagai karunia Tuhan Yang Maha Esa terhadap bangsa dan negara Indonesia; (3) proses kelahiran manusia Indonesia dengan rasa bersyukur; (4) nilai-nilai peradaban dunia yang menghargai perbedaan sebagai karunia Tuhan yang Maha Esa; dan (5) pengamalan hikmah kemerdekaan sebagai tanda syukur kepada Tuhan YME, dalam kegiatan membangun kehidupan berbangsa dan bernegara.

IPS-Sosiologi memfokuskan pada pembentukan sikap: (1) mensyukuri keberagaman agama dalam kehidupan sosial dan budaya sebagai anugerah Tuhan Yang Maha Kuasa; (2) memahami, menerima, dan menghargai perbedaan kegiatan ritual sebagai akibat (implikasi) dari keberagaman ajaran agama yang dianut. IPS-Ekonomi memfokuskan pada pembentukan sikap: (1) mensyukuri sumber daya karunia Tuhan YME dalam rangka pemenuhan kebutuhan; (2) mengamalkan ajaran agama dalam pengelolaan akuntansi, keuangan bank dan lembaga keuangan lainnya, usaha dan koperasi. IPSAntropologi difokuskan pada pembentukan sikap: (1) mensyukuri keberagaman agama, budaya, tradisi dan bahasa dalam kehidupan sebagai anugerah Tuhan Yang Maha Kuasa; (2) memahami, menerima, dan menghargai perbedaan kegiatan ritual sebagai akibat (implikasi) dari keberagaman ajaran agama yang dianut.

IPS-Geografi memfokuskan pada pembentukan kesadaran dan sikap: (1) menghayati keadaan alam semesta beserta segala keberagaman isi dan potensinya sebagai karunia dan ciptaan Tuhan Yang Maha Kuasa; (2) mensyukuri penciptaan bumi tempat kehidupan sebagai karunia Tuhan Yang Maha Pengasih; dan keberadaan diri sebagai warga negara Indonesia dengan pola pikir dan tindak dengan menunjukkan ketakwaan kepada Tuhan Yang Maha Esa (Kemendikbud, 2013c).

\section{IPS-Tematik: Model Aktualisasi Sikap Keagamaan dalam Ranah Sosial}

Untuk mewahanai distribusi dan integrasi kompetensi sikap kegamaan di dalam mata pelajaran IPS, kurikulum 2013 mengembangkan model pembelajaran "tematik", yaitu pembelajaran yang berpusat pada sejumlah tema-topik, ide atau konsep utama - sebagai penginte- 
grasi kompetensi, dan konsep dasar berbagai mata pelajaran. Tema merupakan sebuah cara mengorganisasikan pengetahuan tentang pengalaman manusia, dan mengkonstitusinya dalam jaringan organisasi program IPS sejak jenjang PAUD (pre-K) hingga kelas 12 (K-12) (NCSS, 2010). Melalui pendekatan tema (tematik) peserta didik tidak mempelajari konsep dasar semata, melainkan dengan cara membangun kaitankaitan di dalam pengetahuan, keterampilan, dan sikap, dan menyediakan pengalaman belajar yang luas dan kaya antara apa yang dipelajari dengan kehidupan nyata (Ward, 2003).

Pendakatan tematik pertama kali dikembangkan oleh NCSS di dalam National Curriculum Standards for Social Studies tahun 1994 dan revisinya tahun 2010. Di dalam standar-standar tersebut, NCSS telah mengembangkan dan menggunakan 10 tema kajian kurikuler IPS dari jenjang TK (Pre-K) hingga jenjang kelas 12 (K-12). Dari sepuluh tema tersebut, kajian tentang agama terdistribusi dan terintegrasi di dalam dua tema: (1) budaya (culture), difokuskan pada pemberian pengalaman belajar tentang kaitan timbal-balik agama dengan berbagai aspek budaya lainnya seperti politik, institusi sosial, sastra, musik, dan seni; dan (2) individu, kelompok, dan institusi (individuals, groups, and institutions), difokuskan pada pemberian pengalaman belajar tentang peran organisasi sosial keagaman dalam membangun nilai-nilai sosial inti bagi kehidupan keseharian, mendorong keberlanjutan sosial, mediasi konflik, dan menanggapi isu-isu publik.

Melalui tema-tema tersebut, kajian keagamaan di dalam IPS diharapkan mampu meningkatkan kesadaran dan pengertian peserta didik tentang keberagaman agama, pengalaman dan ekspresi keagamaan, dan dasar-dasar pemikiran tentang pengekspresian keyakinan beragama di dalam masyarakat dan budaya. Sejumlah studi empirik menunjukkan bahwa pendekatan tematik sangat bermakna untuk memfasilitasi banyaknya bahan-bahan belajar dan memudahkan peserta didik untuk mengorganisasi dan menguasainya dengan baik (Wurman, et al., 2000).

Pendekatan tematik juga mampu meningkatkan kemampuan siswa menuntaskan tugas-tugas belajarnya, serta membangun kesadaran-diri mereka atas kapasitas kognitif, afektif, dan keterampilan motorik yang dimiliki secara utuh (Dilek, 2007; Sukadi, 2005). Studi Andayani (2008) juga menyimpulkan bahwa pendekatan tematik mampu meningkatkan aktivitas dan efektivitas interaksi dan komunikasi multi-arah antara siswasiswa, siswa-guru; siswa mampu mengungkapkan ide, bertanya, dan menjawab pertanyaan dengan santai dan gembira. 
Seperti halnya standar kurikulum NCSS, di dalam konteks kurikulum 2013 juga telah dikembangkan sejumlah tema untuk IPS khusus untuk jenjang SD/MI. Sedangkan pada jenjang SMP/MTs - dan SMA/MA - tetap menggunakan pendekatan pokok-pokok bahasan yang dikembangkan atas dasar 'konsep konektivitas' ruang dan waktu beserta aktivitas-aktivitas sosial di dalamnya, dengan menempatkan kajian bidang geografi sebagai landasan (platform) pembahasan bidang ilmu yang lain (Setiawan et al., 2013).

Pada tahap awal (tahun pertama) implementasinya, ada 4 (empat) tema dan sub-sub tema masing yang telah dikembangkan di dalam IPS untuk kelas I dan IV SD/MI. Tema-tema tersebut dipilih dan dikembangkan terkait dengan alam dan kehidupan manusia yang dekat dan bisa dialami secara langsung oleh peserta didik (Kemendikbud, 2012a). Tema juga dapat dipilih dan dikembangkan dari sejumlah isu, peristiwa, dan/atau masalah yang berkembang di masyarakat, dan dirumuskan dalam bentuk 'situasi bermasalah' (problematic condition), sehingga dapat dikaji dan dipecahkan dari berbagai sudut pandang disiplin ilmuilmu sosial secara terpadu (Noviani, 2010). Beberapa contoh isu, peristiwa, dan masalah sosial yang dapat dijadikan tema antara lain: masalah lalu lintas dan transportasi (Andayani, 2008); kegiatan ekonomi masyarakat; masalah lingkungan hidup dan upaya penanggulangannya; pelestarian ling-kungan; atau penyimpangan sosial dalam masyarakat (Noviani, 2010).

Berikut adalah tema-tema IPS kelas I dan IV.

Kelas I. Tema 1: Diriku, dengan sub-sub tema: Aku dan Teman Baru, Tubuhku, Aku Merawat Tubuhku, dan Aku Istimewa. Tema 2: Kegemaranku, dengan sub-sub tema: Gemar Berolahraga, Gemar Bernyanyi dan Menari, Gemar Menggambar, dan Gemar Membaca. Tema 3: Kegiatanku, dengan sub-sub tema: Kegiatan Pagi Hari, Kegiatan Siang Hari, Kegiatan Sore Hari, dan Kegiatan Malam Hari.Tema 4: Keluargaku, dengan sub-sub tema: Anggota Keluargaku, Kegiatan Keluargaku, Keluarga Besarku, dan Kebersamaan dalam Keluarga.

Kelas IV. Tema 1: Indahnya Kebersamaan, dengan sub-sub tema: keberagaman budaya bangsaku, kebersamaan dalam keberagaman, bersyukur atas keberagaman, dan bangga pada budayaku. Tema 2: Selalu Berhemat Energi, dengan sub-sub tema: macammacam sumber energi, pemanfaatan energi, gerak dan gaya. Tema 3: Peduli terhadap Makhluk Hidup, dengan subsub tema: hewan dan tumbuhan di 
lingkungan rumahku, keberagaman makhluk hidup di lingkunganku, ayo cintai lingkungan, dan makhluk hidup di sekitar kita. Tema 4: Berbagi Pekerjaan, dengan sub-sub tema: jenis-jenis pekerjaan, barang dan jasa, pekerjaan orang tuaku, dan pekerjaan di sekitarku.

Di kelas I SD, pengembangan sikap agama melalui keempat temanya difokuskan pada rekonstruksi pengertian dan kesadaran kepada peserta didik tentang makna 'bersyukur kepada Tuhan'. Tema-1 (Diriku), membelajarkan tentang anggota tubuh dan manfaatnya; makna hidup, tubuh sehat, menjadi anak baik; buah kesukaan; teman laki-laki dan perempuan; dan perbedaan kesukaan sebagai anugerah Tuhan (Assagaf, et al., 2013a). Tema-2 (Kegemaranku), membelajarkan tentang makna olah raga untuk menjaga kekuatan dan kesehatan tubuh (Assagaf, et al., 2013b). Tema-3 (Kegiatanku), membelajarkan tentang makna matahari dan cahayanya, udara; keteraturan alam semesta ciptaan Tuhan Maha Pencipta dan Maha Besar dalam pergantian waktu pagi, siang, sore, dan malam sebagai karuniaNya; tata-cara mengambil dan menghabiskan makanan; dan kewajiban mencuci tangan dan berdoa sebelum makan (Assagaf, et al., 2013). Tema-4 (Keluargaku), membelajarkan tentang makna saling menyayangi terhadap sesama anggota keluarga sebagai karunia Tuhan; dan semua makhluk Tuhan, termasuk tanaman. Sikap bersyukur kepada Tuhan juga dibelajarkan melalui nikmat Allah berupa makanan, air, yang bisa dibagi dan dinikmati bersama keluarga dalam suasana yang menyenangkan; arti penting sikap saling menolong/membantu dalam kebersamaan keluarga; rasa cinta kepada keindahan alam ciptaan Tuhan sebagai karuniaNya; dan kegembiraan pada hari raya sebagai pengingat kepada anugerahNya (Lubna Assagaf dkk, 2013d).

Di kelas IV SD, seperti di kelas I pengembangan sikap agama juga difokuskan pada rekonstruksi pengertian dan kesadaran kepada peserta didik tentang makna 'bersyukur kepada Tuhan'. Dari empat tema hanya Tema 2 (Selalu Berhemat Energi) yang sama sekali tidak memuat pembelajaran tentang sikap keagamaan (Afriki et al., 2013b) Tema 1 (Indahnya Kebersamaan), membelajarkan tentang anugerah anggota tubuh dan manfaatnya untuk melihat dan menikmati keindahan ciptaan Tuhan dan manusia; keberagaman tanah air Indonesia dalam bentuk rumah-rumah adat, yang diantaranya juga melambangkan kekuasaan, penghormatan, dan rasa syukur kepada Tuhan dan sesama (mis. rumah adat Tongkonan Sulsel, Lontik Riau); pakaian adat, alat musik, tarian daerah (mis. tari Hudoq Kaltim), bahkan 
makanan (mis. tumpeng). Rasa syukur kepada anugerah Tuhan tersebut disertai dengan bentuk pengamalannya denga cara menjaganya dan melestarikannya (Afriki et al., 2013a). Tema 3 (Peduli Terhadap Makhluk Hidup), membelajarkan tentang keberagaman makhluk hidup (hewan dan tumbuhan), bagian-bagian makhluk hidup beserta fungsi masing masing sebagai tanda kebesaran Tuhan yang mencipta; mencintai dan kasih sayang terhadap makhluk hidup dengan memeliharanya sebagai sesama ciptaan Tuhan (Afriki et al., 2013c). Tema 4 (Berbagi Pekerjaan), membelajarkan tentang keberagaman sumber daya alam merupakan kekayaan alam yang diciptakan oleh Tuhan untuk memenuhi kebutuhan dan kesejahteraan manusia (Afriki et al., 2013d).

Pada jenjang SMP/MTs, sikap keagamaan juga difokuskan pada rekonstruksi pengertian dan kesadaran kepada peserta didik tentang makna 'mengingat dan bersyukur kepada Tuhan' atas segala anugerahNya serta kewajiban untuk memelihara, menghargai, dan menjaganya sebagai wujud syukur kepadaNya. Pengembangannya dilakukan melalui pembelajaran tentang keberagaman kekayaan alam (tanah, air, udara) dan aktivitas penduduk Indonesia dalam memenuhi kebutuhan hidup; waktu dan pemanfaatannya dalam beragam kegiatan/aktivitas manusia; keadaan alam negara Indonesia (suhu, iklim, musim) yang memungkinkan manusia Indonesia beraktivitas dengan nyaman; kekayaan dan keindahan alam (hutan, sungai, danau, gunung dan pegunungan) yang dianugerahkan kepada Indonesia untuk dinikmati dan disyukuri; kesuburan alam (pertanian, perkebunan, kayu) dan berkahnya bagi pemenuhan keperluan sandang, pangan, dan papan bagi bangsa Indonesia; keragaman dan karakteristik potensi wilayah sebagai bukti keadilan Tuhan agar manusia saling mengenal (taarruf) dan berinteraksi (antar-wilayah antar-bangsa, dan antar-negara); dan peran kelembagaan sosial keagamaan bagi kemajuan dan peningkatan kualitas hidup kepentingan keagamaan umat di dalam kehidupan bermasyarakat, berbangsa, dan bernegara.

Keragaman sosial dan budaya Indonesia seperti rumah adat, pakaian adat, senjata tradisional, alat musik, lagu dan tarian daerah, dan pertunjukan rakyat sebagai hasil dari cipta, rasa, dan karsa manusia Indonesia dalam memenuhi kebutuhannya juga dibelajarkan untuk mengingatkan dan menyadarkan peserta didik atas anugerah Tuhan yang patut disyukuri. Bahwa di dalam keberagaman terdapat simbol, lambang kekuasaan, pemujaan, penghormatan, dan rasa 
syukur kepada Tuhan dan sesama yang patut dijaga dan dilestarikan sebagai wujud rasa syukur kepadaNya, dan pengamalan atas ajaran-ajaran agama. Penguasaan ilmu pengetahuan oleh manusia sebagai ciptaan Tuhan yang paling sempurna juga ditekankan untuk menjaga kelestarian alam ciptaan Tuhan bagi keberlanjutan hidup bangsa. Pembelajaran tentang bencana alam sebagai akibat perbuatan manusia, juga mengingatkan tentang 'peringatan dan teguran Allah" atas salah dan khilaf manusia, dan agar kita semua selalu ingat kembali pada Tuhan (Setiawan et al., 2013).

Pada jenjang SMA/MA, pengembangan sikap keagamaan juga dibelajarkan melalui mata pelajaran kelompok peminatan ilmu-ilmu sosial. IPS-Sejarah Indonesia misalnya, membelajarkannya melalui penelusuran sejarah pembentukan kepulauan Indonesia sebagai bagian dari bumi ciptaanNya; peradaban awal manusia Indonesia (sistem kepercayaan); peran alam dalam pertumbuhan kerajaankerajaan Indonesia; aktivitas pelayaran dan perdagangan masa Islam; dan upacara-upacara keagamaan masa kerajaan Islam (mis. grebeg), yang di dalamnya memuat contoh-contoh dan bukti-bukti kearifan, kebijaksanaan, kasih sayang Allah kepada bangsa
Indonesia yang wajib disyukuri (Gunawan et al., 2013).

\section{KESIMPULAN}

Dalam sejarah pengembangan kurikulum di Indonesia, kurikulum 2013 memiliki makna penting dengan penggunaan filsafat Rekonstruksionisme Sosial dan teori Gestalt yang menekan arti penting integrasi, keterpaduan antarkonten kurikulum, dan antara konten kurikulum dengan realitas kehidupan; serta orientasinya pada pembentukan pengetahuan, sikap, dan keterampilan fungsional, dipandang sebagai responsolutif kurikulum atas kebutuhan masyarakat dan bangsa dalam membangun generasi muda bangsanya. Implikasi lebih jauh penggunaan kedua teori-filsafat tersebut adalah adanya rekonstruksi secara mendasar terhadap seluruh struktur substantif kurikulum, mencakup organisasi konten/isi, bahan belajar, mata pelajaran, dan organisasi pembelajaran.

Pengembangan sikap keagamaankognitif, afektif, dan konatif-yang selama ini 'eksklusif' ranah pendidikan Agama, menjadi terbuka, dan 'inklusif' untuk dikembangkan di dalam semua ranah kurikulum dari jenjang SD/MI hingga SMA/MA, kecuali mata pelajaran Matematika. 
Namun demikian, apapun salah satu implikasi penting dari hasil perubahan paradigma yang menjadi landasan pengembangan kurikulum 2013, sukses kurikulum tidak hanya diukur dari dimensi kurikulum sebagai 'ide' atau 'dokumen', melainkan juga dimensi 'praktik' kurikulum dalam praksis pembelajaran di kelas. Dalam kaitan ini, kajian ini adalah perlunya penelitian lapangan atas praktik atau implementasi Kurikulum 2013, sehingga dapat teridentifikasi peluang dan kendala dalam mengimplementasikan ide dan cita-cita kurikuler untuk kepentingan revisi dan/atau pembaharuan Kurikulum 2013.

\section{DAFTAR PUSTAKA}

Afriki dkk. (2013a). Tema 1 Indahnya Kebersamaan. IPS Kelas IV SD/MI. Jakarta: Pusat Kurikulum dan Perbukuan Kemendikbud.

Afriki dkk. (2013b). Tema 2 Selalu Berhemat Energi. IPS Kelas IV SD/MI. Jakarta: Pusat Kurikulum dan Perbukuan Kemendikbud.

Afriki dkk. (2013c). Tema 3 Peduli Terhadap Makhluk Hidup. IPS Kelas IV SD/MI. Jakarta: Pusat Kurikulum dan Perbukuan Kemendikbud.

Afriki dkk. (2013d). Tema 4 Berbagi Pekerjaan. IPS Kelas IV SD/MI. Jakarta: Pusat Kurikulum dan Perbukuan Kemendikbud.

Andayani. (Agustus 2008). "Aplikasi Pendekatan Tematis untuk Pembinaan Kompetensi Komunikatif Bahasa Indonesia Pada Siswa SLTP”, Paedagogia: Jurnal Penelitian Pendidikan, jilid 11, no. 2, pp. 91 - 100.

Assagaf, L. dkk. (2013a). Tema 1 Diriku. IPS Kelas I SD/MI. Jakarta: Pusat Kurikulum dan Perbukuan Kemendikbud.

Assagaf, L. dkk. (2013b). Tema 2 Kegemaranku. IPS Kelas I SD/MI. Jakarta: Pusat Kurikulum dan Perbukuan Kemendikbud.

Assagaf, L. dkk. (2013c). Tema 3 Kegiatanku. IPS Kelas I SD/MI. Jakarta: Pusat Kurikulum dan Perbukuan Kemendikbud.

Assagaf, L. dkk. (2013d). Tema 4 Keluargaku. IPS Kelas I SD/MI. Jakarta: Pusat Kurikulum dan Perbukuan Kemendikbud.

Blogdetik.com. Politik Pendidikan; Sebuah Perspektif Kekinian, Retrieved October 19, 2013, from http://bsy09.blogdetik.com/2009/01/05/politik-pendidikan-sebuahperspektif-kekinian.html.

Brameld, Th. (1965). Education as Power. New York: Holt, Rinehart and Winston, Inc.. Buchori, M. (2001). Pendidikan Antisipatoris. Yogyakarta: Kanisius.

Bussière, P., Cartwright, F., \& Knighton, T. (2004). The Performance of Canada's Youth in Mathematics, Reading, Science and Problem Solving: 2003 First Findings for Canadians Aged 15. Ottawa-Canada: Human Resources and Skills Development Canada, Council of Ministers of Education.

Bussière, P., Knighton, T., \& Pennock, D. (2007). The Performance of Canada's Youth in Science, Reading and Mathematics: 2006 First Results for Canadians Aged 15. Ottawa-Canada: Human Resources and Skills Development Canada, Council of Ministers of Education. 
Collie, William E. \& Smith, Lee H. (1981). 'Teaching About Religion in the Schools: The Continuing Challenge', Social Education, vol. 45(1), pp. 1-16.

Cornbelth, C. (2001). 'Research on Context, Research in Context', James P. Shaver (ed). Handbook of Research on Social Studies Teaching and Learning. New York: Macmillan Publishing Company.

Dahar, Ratna W. (1991). Teori-teori Belajar. Bandung: Erlangga.

Daniel, K. (2011). "Students' Attitudes on the Teaching of Christian Religious Education in Secondary Schools in Kenya," International Journal of Psychology and Behavioral Sciences, vol.1(1), pp. 48-54 DOI: 10. 5923/j.ijpbs.20110101.07

Depdiknas. (1999). Suplemen Garis-garis Besar Program Pengajaran Matapelajaran Ilmu Pengetahuan Sosial di Sekolah Dasar. Jakarta: Pusbangkurrandik.

Depdiknas. (2002). Kurikulum Berbasis Kompetensi Matapelajaran Ilmu Sosial Sekolah Dasar. Jakarta: Pusbangkurrandik.

Dilek, D. (2007). "Using A Thematic Teaching Approach Based on Pupil's Skill and Interest in Social Studies Teaching”, The International Journal, vol. 7(1), pp. 1-8.

Ellis, Arthur K. (1998). Teaching and Learning Elementary Social Studies (6 $6^{\text {th }}$ Edition). Boston: Allyn \& Bacon.

Fajar, A. Malik dkk. (2001). Platform Reformasi Pendidikan dan Pengembangan Sumber Daya Manusia. Jakarta: Logos.

Gagne, Robert M. (1977). The Conditions of Learning. New York: Holt, Rinehart \& Winston.

Gunawan, R. dkk. (2013). Sejarah Indonesia untuk Kelas X. Pusat Kurikulum dan Perbukuan Kemendikbud.

Hasan, A. Hamid. (29 Nopember 2002 ). 'Pendidikan Sebatas Transfer Ilmu', Pikiran Rakyat.

Kaymakcan, R., \& Meydan, H. (2012). "Values in the Curricula of Religious Education and Social Studies in Primary Schools in the Context of Local-Universal Dilemma", Educational Sciences: Theory \& Practice, vol. 12(2) [Supplementary Special Issue], Spring, pp. 1588-1591.

Kemendikbud. (2012). Dokumen kurikulum 2013. Jakarta: Puskur-Kemendikbud.

Kemendikbud. (2013a). Kurikulum 2013: Kompetensi Dasar Sekolah Dasar (SD)/Madrasah Ibtidaiyah (MI). Jakarta: Puskur-Kemendikbud.

Kemendikbud. (2013b). Kurikulum 2013: Kompetensi Dasar Sekolah Menengah Pertama (SMP)/Madrasah Tsanawiyah (MTs). Jakarta: Puskur-Kemendikbud.

Kemendikbud. (2013c). Kurikulum 2013: Kompetensi dasar Sekolah Menengah Atas (SMA)/Madrasah Aliyah (MA). Jakarta: Puskur-Kemendikbud.

Koçoğlu, E. (2016). "Social Studies Teachers' Perspective of Religion Education in Turkey, " International Online Journal of Educational Sciences, vo. 7(1), pp. 145159.

Kosim, M. (2011). “Urgensi Pendidikan Karakter”, Karsa, vol. IXI(1), pp. 85-92.

Koster, W. (2000). 'Pengaruh Input Sekolah terhadap Outcome Sekolah: Survai di SLTP Negeri DKI Jakarta', Jurnal Pendidikan dan Kebudayaan, th. 6(025), pp. 358-368.

Krathwohl, D.R. (ed). (2002). A Taxonomy for Learning, Teaching, and Assessing: A Revision of Bloom's Taxonomy of Educational Objectives. New York: Longman.

Lombok, J.L.L. (2003). 'Peningkatan Mutu Luaran Pendidikan Dasar dan Menengah dalam Mendukung Terwujudnya Perguruan Tinggi Yang Tangguh', Jurnal Pendidikan dan Kebudayaan, th. 9(044), pp. 602-617. 
NCSS. (1989). Charting A Course: Social Studies for the 21st Century. USA: NCSS.

NCSS. (1994). Expectations of Excellence: Curriculum Standards for Social Studies. Washington, D.C.: National Council for the Social Studies.

NCSS. A Vision of Powerful Teaching and Learning in the Social Studies: Building Social Understanding and Civic Efficacy. Retrieved October 23, 2016 from http://www.socialstudies.org/

NCSS. Curriculum Guidelines for Social Studies Teaching and Learning. Retrieved October 23, 2016 from http://www.socialstudies.org/.

NCSS. National Curriculum Standards for Social Studies: A Framework for Teaching, Learning, and Assessment. Silver Spring, MD: NCSS, 2010.

NCSS. Study about Religions in the Social Studies Curriculum. Retrieved October 23, 2016 from http://www.socialstudies.org/

Noviani, L. (2010). "Peningkatan Kemampuan Berpikir Kritis Melalui Integrated Learning Pada Mata Pelajaran IPS SMP”, Paedagogia: Jurnal Penelitian Pendidikan, vol. 13(2), pp. 173 - 187.

Ogawa, M. "Science As the Culture of Scientist: How to Cope with Scientism?" Retrieved January 27, 2017 from www.ouhk.edu.hk/cridal/misc/ogawa.html.

Ozer, A. et.al., (2012,). 'Determining Candidates of Religion Culture and Moral Knowledge Teachers' Attitude Towards Art and Role of Art in Contributing to Their Personal Development', Procedia - Social and Behavioral Sciences, vol. 51, pp. $1039-1043$.

Ricoeur, P. (1991). From text to action: Essays in hermeneutics. Illinois: Northwestern University Press.

Setiawan, I. dkk. (2013). Ilmu Pengetahuan Sosial Kelas VII SMP/MI. Jakarta: Kemendikbud.

Soedijarto. (2004). 'Kurikulum, Sistem Evaluasi, dan Tenaga Pendidikan sebagai Unsur Strategis dalam Penyelenggaraan Sistem Pengajaran Nasional', Jurnal Pendidikan Penabur, th.III(3), pp. 89-107.

Somantri, N. (2000). Menggagas Pembaharuan Pendidikan IPS. Dedi Supriadi \& Rohmat Mulyana, eds., Bandung: PPS-FPIPS UPI dan PT. Remadja Rosda Karya.

Sraman, S. (2012). 'Buddhist Attitude Towards Culture and Other Religions', Proceedings Archi-Cultural Translations through the Silk Road 2nd International Conference. Mukogawa Women's University, Nishinomiya, Japan, pp. 296-3001.

Stemler, S. (2012). An Overview of Content Analysis. Practical Assessment, Research \& Evaluation, 7(17): 1-10.

Sukadi, (2005). "Pendidikan IPS Yang Powerful dalam Kurikulum Berbasis Kompetensi", Jurnal Pendidikan dan Pengajaran, Th. XXXVIII(4), pp. 1-23.

Sumantri, M. (2002). Pengembangan Potensi Siswa dengan Kurikulum Terpadu untuk Menjadi Manusia Indonesia Seutuhnya. Pidato Pengukuhan Jabatan Guru Besar Tetap dalam Bidang Ilmu Perencanaan Kurikulum pada FIP-UPI. Bandung: UPI.

Supriyoko, K. (8 Juni 2001). 'Menuai Dampak Panjang Pendidikan', Harian Suara Pembaharuan.

Suyanto. (6 Oktober 2003). 'Persoalan Implementasi Kurikulum Berbasis Kompetensi', Kompas, Didaktika.

Wahab, A. Azis. (1986). Materi Pokok Metodologi Pendidikan IPS. Jakarta: Universitas Terbuka. 
Ward, G. (2003). 'Using Theme Cycles', Total Literacy: Reading, Writing and Learning. Belmont, CA: Wadsworth/Thomson Learning, pp. 439-465.

Welton, David A. \& Malan. (2004). Children and Their World: Strategies for Teaching Social Studies. Boston: Houghton Mifflin College Div.

Wertheimer, M. (1999). "Gestalt Theory”, Gestalt Theory Jurnal, vol. 21(3), pp. 181183.

Winataputra, Udin S. (2001a). Jatidiri Pendidikan Kewarganegaraan sebagai Wahana Sistemik Pendidikan Demokrasi: Suatu Kajian Konseptual dalam Konteks Pendidikan IPS. Disertasi tidak dipublikasikan. Bandung: Program Pasca Sarjana Universitas Pendidikan Indonesia.

Winataputra, Udin S. (2001b). Reorientasi Pendidikan Ilmu Pengetahuan Sosial Mengantisipasi Perubahan Sosial di Era Global. Makalah disajikan dalam Seminar Nasional dan Kongres Forum Komunikasi X Pimpinan FPIPS/FIS/FKIP Universitas/IKIP se Indonesia serta Kongres HISPIPSI. Universitas Negeri Semarang, 22-24 Oktober 2001.

Wurman, Richard S. et al., (2000). Information Anxiety 2. New York; QUE.

Zhang, Y. , \& Wildemuth, B. M. (2009). Qualitative analysis of content. In B. Wildemuth (Ed.), Applications of Social Research Methods to Questions in Information and Library Science (pp.308-319). Westport, CT: Libraries Unlimited. 